\title{
Project Activities and Encouraging Critical Thinking: Exploring Teachers' Attitudes
}

Petra Pejić PapaK ${ }^{\star 1}$, Lidija Vujičić ${ }^{2}$ ANd ŽEljka Ivković ${ }^{3}$

$\approx$ The contemporary education process frequently emphasises the importance of teaching and learning by focusing teaching activities towards research and collaborative work, the encouragement of critical thinking, the creative and productive application of knowledge, an active approach to the teaching content, and solving specific problems in project activities. A survey was conducted on a sample of 220 elementary school teachers from three counties in Croatia (Primorje-Gorski Kotar, Lika-Senj, and Istria) regarding the frequency of implementing project activities that encourage critical thinking in pupils. The objectives of the research were to determine the regularity of implementing project activities at the class level and at the level of the entire school, and to examine possible differences between teachers who estimated regular implementation of project activities in their schools and those who estimated the levels of irregular implementation of project activities, in the application of contemporary work strategies, as well as in the attitudes on the contemporary paradigm of childhood and the education process. The research results showed that the majority of teachers estimated that project activities were carried out regularly at their school (66.5\% on a class level and $65 \%$ on a school level). Teachers who reported the regular implementation of project activities at the class level and at the school level more frequently applied contemporary work strategies and techniques of critical thinking than their colleagues did. The research results also indicated that those teachers more frequently use established approaches to the educational process (teacher should explain, exhibit facts, and point out important conclusions) than their colleagues do. There were no statistically significant differences in contemporary attitudes between the two groups of teachers. Since the objective behind the implementation of project activities was to create the knowledge that, in the creative act, boundaries of the known or tried are transcended in the direction of new and expanded knowledge, importance should be given to the role of teachers in promoting the development of critical thinking and guiding pupils to explore and discover new knowledge.

Keywords: critical thinking, project teaching, teaching strategies, teacher

${ }^{\star}$ Corresponding Author. University of Rijeka, Faculty of Teacher Education, Croatia; petra@ufri.hr. University of Rijeka, Faculty of Teacher Education, Croatia.

University of Rijeka, Faculty of Teacher Education, Croatia. 


\section{Projektno učno delo in spodbujanje kritičnega mišljenja: raziskovanje stališč učiteljev}

Petra Pejić PAPAK, Lidija Vujičić in ŽEljka Ivković

$\approx \mathrm{V}$ sodobnem vzgojno-izobraževalnem procesu je pogosto poudarjena pomembnost poučevanja in učenja, ki sta osredinjena na raziskovalno in skupinsko delo, spodbujanje kritičnega mišljenja, ustvarjalnost in uporabnost znanja, aktiven pristop do učne vsebine ter na reševanje specifičnih problemov s projektnim učnim delom. Raziskava je bila izvedena na vzorcu 220 osnovnošolskih učiteljev iz treh okrožij na Hrvaškem (Primorje Gorski kotar, Lika - Senj in Istra) z namenom ugotavljanja pogostosti uporabe projektnega učnega dela, ki spodbuja kritično mišljenje učencev. Cilji raziskave so bili ugotoviti pogostost uporabe projektnega učnega dela na ravni razreda in ravni celotne šole ter preučiti mogoče razlike med učitelji, ki so ocenili, da redno izvajajo projektno delo na njihovi šoli, in tistimi, ki so ocenili, da projektno učno delo izvajajo samo občasno, in sicer $\mathrm{z}$ vidika uporabe sodobnih didaktičnih pristopov in $\mathrm{z}$ vidika učiteljevih stališč do vzgojno-izobraževalnega procesa. Raziskovalni rezultati so pokazali, da je večina učiteljev ocenila, da projektno učno delo na njihovi šoli redno izvaja $(66,5 \%$ na ravni razreda in $65 \%$ na ravni šole). Učitelji, ki so poročali o redni uporabi projektnega učnega dela na ravni razreda in ravni šole, so pogosteje uvajali sodobne didaktične strategije in tehnike kritičnega mišljenja kot njihovi kolegi. Raziskovalni rezultati so pokazali tudi, da ti učitelji pogosteje uporabljajo uveljavljene pristope v učnem procesu (učitelj mora razložiti in predstaviti dejstva ter poudariti pomembne sklepe) kot njihovi kolegi. Med obema skupinama učiteljev se niso pokazale statistično pomembne razlike na ravni stališč. Glede na to, da je bil cilj uvajanja projektnega učnega dela pridobiti znanje, ki na ustvarjalen način presega meje znanega, je pomembno poudariti vlogo učiteljev pri spodbujanju razvoja kritičnega mišljenja in usmerjanju učencev k raziskovanju novega znanja.

Ključne besede: kritično mišljenje, projektno učno delo, didaktične strategije, učitelj 


\section{Introduction}

The contemporary requirements of the educational process focus on the detection, development of autonomy, competence, innovation, ability of reflection, and the renewal of skills, as well as forming a better and more humane relationship between acquiring knowledge for life. In other words, the process of learning in contemporary educational work is discussed from a humanistic approach that places pupils in the center of the learning process and, through pupil-centred teaching, encourages and supports the development of pupils' abilities, thereby respecting their needs, desires, and the will for self-realisation. 'Learning that places the pupil in the center is valuable because the pupil develops responsibility, becomes more motivated and more involved in the decision making, and the results are increased and more pupils enjoy teaching' (Jensen, 2003, p. 93). We wish to emphasise that teaching activities oriented towards research and collaborative work, i.e. towards discovering knowledge and the productive application of knowledge provide access to learning and teaching during which the pupils create, discover, independently plan, take initiative, ask questions, and investigate. 'Linking knowledge with personal experiences and knowledge, experiences from everyday life with the knowledge of other subjects and areas is especially encouraged' (Bezinović et al. 2012, p. 40). Pupils are required to understand, to express their own viewpoints on certain phenomena, to think critically, to engage in a creative approach to solving problems, and not just to reproduce content.

\section{Critical Thinking in Project Teaching}

In the contemporary educational process, it is important to move the focus from the paradigm of teaching-learning towards a concept centred on active learning. Active learning is the kind of learning through which a high degree of autonomy and self-regulation are achieved, and in which various strategies and methods are applied (Peko \& Varga, 2014). The term educational strategy includes 'a planned combination of methods and procedures to encourage the pupil's activity and enables his own learning process to achieve the aims of education' (Cindrić et al. 2010, p. 170). The strategy of learning through exploration is thereby given particular significance as part of collaborative work strategies because its application encourages the pupils to learn based on personal experiences. Since 'the goal of learning through exploration is to transcend the available material, the fact is that in learning through exploration the pupil in the creative act transcends the boundaries of the transferred, i.e. of the already known or tried in the direction of new and expanded knowledge' (Terhart, 2001, p. 157). 
With regards to content and interest-cognitive activities, which the teacher organises as part of the teaching process, we divided the strategy of learning through exploration, which is characterised by experiential learning, into three methods according to Bognar and Matijevic (2002, p. 275): research, simulation, and project, which, in practical use are found in numerous procedures. The project method, also known as project work, project approach, and project-based learning, is one of the standard methods of teaching (Knoll, 2014). The term 'educational project' or 'teaching project' is used for projects that are realised at the school or for teaching whose objective is the achievement of learning goals (Matijević \& Radovanović, 2011). Terminologically, it implies planned and designed teaching that aims to achieve essential knowledge and results based on researching a certain situation. The teaching project is a complex process that starts with a predetermined plan and is aimed at achieving the goals or objectives of learning and education, to solve specific problems.

Similarly, for Cindrić et al. (2010), a project is a complex task with a clearly set objective whose result is a specific action. Čulina-Obradović and Brajković (2009, p. 53) understand project activity as 'an open form of teaching considering that there is openness in decision-making within the flow, and the product or result develops successively from the teaching process', while Cindrić et al. (2010) define project teaching as an extensively planned and designed course that aims to reach cognition through research of a certain situation based on interactive learning. Project teaching means working together with pupils, teachers, professional associates, and other factors (Vuković, 2003) and is based on the pupils' independent work in the natural reality. Meyer (2002, p. 180) defines the term project as:

a joint effort of teachers and pupils to connect life, learning, and work in such a way that a socially significant and with the interests of the participants related problem that is mutually processed and leads to results that is of use value to the participants. At the same time, it strives to achieve a balanced relation between mental and physical labor.

It can be concluded that project teaching is a highly complex task, which is based on an interesting content or a problem, that requires of the pupil to set the research, to investigate and resolve a previously set problem within a extended period of time, and to create a final product or result that is publicly presented in its final stage.

Based on the results of the pupils' research projects in teaching, Fabijanić (2014) emphasises that project teaching is applicable to regular classes, during field trips, extracurricular activities, in the processing of inter-disciplinary 
content, and is indispensable in working with gifted pupils. Project work is suitable for the self-organisation of learning since it allows practical training activities and thus provides experience in team and/or group work. It is generally considered to be the way in which pupils can develop independence and responsibility, social and democratic ways of behavior (Knoll, 1997), as well as techniques of critical thinking.

John Dewey is considered to be the originator of critical thinking. $\mathrm{He}$ viewed it as reflective thinking and defined it as an active, diligent, and thorough review process of beliefs with the consideration of those items that support this belief. The teaching of the techniques of critical thinking is most effective and most natural when it occurs indirectly through teaching specific content in the educational process. Danielson (2013) presents a framework for formal classroom education that specifies teaching activities at various stages of the education process. She identifies four areas: planning and preparation, classroom environment, instruction, and professional responsibility. Within each area, she identifies specific activities.

Thinking critically does not mean thinking negatively. It is an impartial and objective process of evaluating the claims and opinions of others. That is why Bowel and Kemp (2010) point out that in critical thinking importance should be given to reflection and finding reasons by using the question word 'why', i.e. finding justification for the claim which is used as an argument. The best way to develop and master critical thinking among pupils is to incorporate it in the access to activities.

Concept mapping has been validated as an effective technique for facilitating critical thinking. The graphic display of a concept map is determined by the logical structure of the complex concept being illustrated (Harris \& Zha, 2013). Critical thinking should be seen as an educational concept whose elements (such as critical listening, reading, and writing) are an important part of the positive development of education. The teacher's approach should also be considered since the teacher should:

ensure the time and opportunity to practice critical thinking, (s)he should allow the pupils to contemplate and theorize, to accept a variety of ideas and opinions, to promote active involvement of pupils in the learning process, to provide the pupils with a risk-free environment with no possibility of ridicule, to express the belief in the ability of all pupils to make critical judgments, and (s)he should appreciate critical thinking. (Steele et al., 2001, p. 9)

This approach to learning through exploration of the topics that pupils 
are interested in will result in a high level of motivation, the development of basic skills and knowledge, as well as specific skills and knowledge that go beyond the curriculum.

\section{Methodology}

\section{The Aim of the Research}

The aim of this research was to examine the attitudes of teachers regarding the application of techniques of critical thinking by implementing project activities at the class level and at the level of the entire school.

\section{The Research Objectives}

1. to identify the frequency of the implementation of project activities at the class level and the level of school with regards to the participants' county and the level of their education;

2. to examine possible differences between teachers who reported the regular implementation of project activities and those who reported the irregular implementation of project activities in their school, in the application of contemporary strategies, with an emphasis on the techniques of critical thinking, and in their attitudes on the contemporary paradigm of childhood and the educational process.

\section{Data collection}

The survey was conducted during May 2015 in Primorje-Gorski Kotar, Lika-Senj, and Istria counties. The participation in the research was anonymous and voluntary. The data were collected by attendance at three teacher training sessions (one session in each county) organised by the Croatian Education and Teacher Training Agency, at which teachers of various schools of the mentioned counties were present. The questionnaires were handed out to teachers at the beginning of the session, and they completed them in approximately 20 minutes. A total of 230 questionnaires were distributed, 220 of which were returned fully completed.

\section{Participants}

In total, 220 elementary school teachers were included in the sample. Most of the respondents were, as expected, female (95.5\%). The youngest participant was 24 and the oldest 64 years old, and the average age was 40.53 years. The level of education of the majority of teachers in the sample was university graduate $(67.6 \%)$, while the minority had a finished college education (32.4\%). 
At the level of the researched counties, data was collected from an almost equal number of teachers: $36.4 \%$ were from Primorje-Gorski Kotar County, 33.2\% from Istria County, and 30.5\% from Lika-Senj County.

\section{Measures}

Teachers' estimation of the regularity of the implementation of project activities in their school was measured with two items: 'The implementation of project activities at the class level is regular' and 'The implementation of project activities at the level of the entire school is regular', on a five-point scale (1='does not apply', 2='mostly does not apply', $3=$ ='neither applies nor does not apply', 4='mostly applies', and 5='fully applies').

The frequency of teacher's individual application of contemporary work strategies and techniques of critical thinking in their class was measured on a Likert-type scale accompanied by a five-point frequency scale (1='never', 2 ='rarely', 3 ='sometimes', 4 ='frequently', 5 ='always'). The instrument included seven items: 'application of group activities', 'organisation of individualised work', 'application of problem teaching, 'exploratory learning through research', 'exploratory learning through simulation', 'integrated theme days in the form of project teaching', and 'application of the technique of critical thinking'.

Teachers' attitudes to the contemporary paradigm of childhood and the educational process were measured on a Likert-type scale accompanied by a five-point assessment scale ( $1=$ 'fully disagree', $2=$ 'mostly disagree', $3=$ 'I do not agree or disagree', $4=$ 'mostly agree', $5=$ 'fully agree'). The instrument included six items: 'Pupils should be allowed to discover their own truths and theories (even if inaccurate) through active and direct research, but they should not be taught facts', 'A pupil learns best in those activities that have been planned and designed by the teacher,' 'For successful learning of more demanding content (e.g. scientific phenomena) it is necessary that the teacher lead and direct activities, while the pupil can learn less demanding content on his own', 'The process in which the pupil seeks a solution is more important than the result itself", 'Pupils should be allowed to create, plan, and manage their activities instead of activities being precisely planned by the teacher', and 'For the pupil to actually learn something it is important that the teacher teach the content, demonstrate, explain, reveal facts, and highlight important conclusions'.

The socio-demographic indicators examined were gender (dichotomous variable), age (open question), educational level (two categories: college and university degree), and the county where the participants work (Primorje-Gorski Kotar (PGŽ), Istra (IS), and Lika-Senj (LS) counties). 


\section{Statistical Analysis}

The data were processed with the statistical package IBM SPSS Version21. The t-test for independent samples was used to compare the results of those teachers who reported the regular implementation of project activities in their schools and those that reported irregular implementation of project activities given the application of different contemporary work strategies and attitudes regarding the contemporary paradigm of childhood, while the t-test for independent samples and ANOVA were used to determine the differences in socio-demographic indicators with respect to the said elements. The chi-square test was used to test the association between regularity in the implementation of project activities and socio-demographic indicators.

\section{Results and Discussion}

\section{Regularity of the Implementation of Project Activities in Schools}

Joint initiatives of teachers and pupils to connect completed, wholesome, and complex content, learning, and work in a way that an interesting problem is processed and leads to results that are useful to the participants and are presented to the wider community, opens the space for project activities.

Teachers' estimation of the regularity of the implementation of project activities in their schools was almost equal at the class level and at the level of the entire school, i.e. the teachers reported at both levels that more project activities were conducted regularly than irregularly. At the class level, $43.1 \%$ of teachers noted that the regularity of project activities mostly applied to their school and $23.4 \%$ of teachers observed that it fully applied to their school, while the least of them stated that this did not apply to their school $(2.8 \%)$ or that it mostly did not apply to their school (11.0\%), and $19.7 \%$ of teachers assessed that it neither applied nor did not apply to them. Similar results were obtained for the level of the entire school: $44.5 \%$ of teachers observed that the regularity of project activities applied to their school, while $20.5 \%$ of teachers noted that it fully applied to their school; the least of them stated that it did not apply (2.7\%) or mostly did not apply to their school $(6.4 \%)$ and $25.9 \%$ of teachers expressed the view that it neither applied nor did not apply to their school.

To facilitate comparisons of teachers who reported the regular and irregular implementation of activities at both levels, we transformed two five-point variables into two dichotomous variables, linking the first three degrees ('does not apply', 'mostly does not apply', and 'neither applies nor does not apply') into the category 'irregular project activity' and the other two degrees ('mostly applies' and 'fully applies') into the category 'regular project activities' (Table 1). 
Table 1

Project activities at the class level and at the school level

\begin{tabular}{lcclcc}
\hline The class level & $\mathbf{f}$ & $\%$ & The school level & $\mathbf{f}$ & $\%$ \\
\hline Irregular project activities & 73 & 33.5 & Irregular project activities & 77 & 35.0 \\
Regular project activities & 145 & 66.5 & Regular project activities & 143 & 65.0 \\
\hline Total & 218 & 100.0 & Total & 220 & 100.0 \\
\hline
\end{tabular}

At the class level, project activities were carried out regularly in $66.5 \%$ of cases, and irregularly in $33.5 \%$ of cases, while at the level of the entire school such activities were carried out regularly in $65.0 \%$ of cases, and irregularly in $35.0 \%$ of cases (Table 1 ). The conclusion is that there was almost no difference in the expressed regularity in the implementation of project activities at the class level and the entire school.

A Chi-square test $\left(\chi^{2 \star}=6.429, \mathrm{df}=1, \mathrm{p}=.01\right.$; Cramer's $\mathrm{V}=171, \mathrm{p}=$ .01) showed that, depending on the level of education, teachers with university education reported more regular implementation of projects at the school level (73.4\%) than teachers with college education did (26.6\%), while there was no statistically significant correlation in the regularity of implementation of project activities at the class level (Table 2).

Table 2

Implementation of project activities with respect to the teacher's education degree

\begin{tabular}{lcccc}
\hline \multirow{2}{*}{ The school level } & & \multicolumn{2}{c}{ Level of education } & \multirow{2}{*}{ Total } \\
\cline { 3 - 4 } & & College degree & University degree & \\
\hline \multirow{3}{*}{ Irregular project activities } & $\mathrm{f}_{\mathrm{t}}$ & 33 & 43 & 76 \\
& $\mathrm{f}_{\mathrm{e}}$ & 24.6 & 51.4 & 76.0 \\
& $\%$ & 43.4 & 56.6 & 100.0 \\
\hline \multirow{3}{*}{ Regular project activities } & $\mathrm{f}_{\mathrm{t}}$ & 38 & 105 & 143 \\
& $\mathrm{f}_{\mathrm{e}}$ & 46.4 & 96.6 & 143.0 \\
& $\%$ & 26.6 & 73.4 & 100.0 \\
\hline \multirow{2}{*}{ Total } & $\mathrm{f}_{\mathrm{t}}$ & 71 & 148 & 219 \\
& $\mathrm{f}_{\mathrm{e}}$ & 71.0 & 148.0 & 219.0 \\
& $\%$ & 32.4 & 67.6 & 100.0 \\
\hline
\end{tabular}

Note. $\chi^{2}=6.429, d f=1, p<.05$. Cramer's $V=.171, p<.05$

In view of the regularity of implementing project activities at the class level by county (Table 3 ), according to the results of the chi-square test $\left(\chi^{2}=\right.$ 
15.492, df $=2, \mathrm{p}=.001$; Cramer's $\mathrm{V}=267, \mathrm{p}=.001$ ), teachers from PrimorjeGorski Kotar County reported a more regular implementation of projects at the level of class teaching (44.8\%) than teachers from Istria (28.3\%) and Lika-Senj (26.9\%) counties did.

Table 3

Implementation of project activities by county (at the class level and at level of the entire school)

\begin{tabular}{lcccc}
\hline & & \multicolumn{3}{c}{ The class level } \\
\cline { 3 - 5 } & & PGŽ & I & LS \\
\hline \multirow{3}{*}{ Irregular project } & $\mathrm{f}_{\mathrm{t}}$ & 13 & 32 & 28 \\
activities & $\mathrm{f}_{\mathrm{e}}$ & 2.1 & 24.4 & 22.4 \\
& $\%$ & 17.8 & 43.8 & 38.4 \\
\hline \multirow{3}{*}{ Regular project } & $\mathrm{f}_{\mathrm{t}}$ & 65 & 41 & 39 \\
activities & $\mathrm{f}_{\mathrm{e}}$ & 51.9 & 48.6 & 44.6 \\
& $\%$ & 44.8 & 28.3 & 26.9 \\
\hline \multirow{4}{*}{ Total } & $\mathrm{f}_{\mathrm{t}}$ & 78 & 73 & 67 \\
& $\mathrm{f}_{\mathrm{e}}$ & 78.0 & 73.0 & 67.0 \\
& $\%$ & 35.8 & 33.5 & 30.7 \\
\hline
\end{tabular}

\begin{tabular}{lcccc}
\hline & & \multicolumn{3}{c}{ The school level } \\
\cline { 3 - 5 } & & PGŽ & $\mathrm{l}$ & LS \\
\hline \multirow{3}{*}{ Irregular project } & $\mathrm{f}_{\mathrm{t}}$ & 13 & 38 & 26 \\
activities & $\mathrm{f}_{\mathrm{e}}$ & 8.0 & 25.6 & 23.5 \\
& $\%$ & 16.9 & 49.4 & 33.8 \\
\hline \multirow{3}{*}{ Regular project } & $\mathrm{f}_{\mathrm{t}}$ & 67 & 35 & 41 \\
activities & $\mathrm{f}_{\mathrm{e}}$ & 52.0 & 47.5 & 43.6 \\
& $\%$ & 46.9 & 24.5 & 28.7 \\
\hline \multirow{4}{*}{ Total } & $\mathrm{f}_{\mathrm{t}}$ & 80 & 73 & 67 \\
& $\mathrm{f}_{\mathrm{e}}$ & 80.0 & 73.0 & 67.0 \\
& $\%$ & 36.4 & 33.2 & 30.5 \\
\hline
\end{tabular}

Note. PGŽ = Primorje-Gorski Kotar county; I = Istria county; LS = Lika-Senj county. $\chi^{2}=15.492, \mathrm{df}=2, \mathrm{p}<.01$. Cramer's $V=.267, \mathrm{p}<.01 . \quad \chi^{2}=22.123, \mathrm{df}=2, \mathrm{p}<.01$. Cramer's $\mathrm{V}=.317, \mathrm{p}<.01$.

Furthermore, the results of the chi-square test $\left(\chi^{2}=22.123, \mathrm{df}=2, \mathrm{p}=\right.$ .oo1; Cramer's V = 317, p = .oo1) (Table 3) showed that teachers from the Primorje-Gorski Kotar County reported more regular project implementation at the level of the entire school (46.9\%) than teachers from the Istria $(24.5 \%)$ and Lika-Senj (28.7\%) counties did.

Statistically significant differences were determined between regular and irregular implementations of project activities in almost all tested categories. Positive sides of implementing project teaching as a form of integrated teaching that is pupil-oriented are, according to Crnković-Nosić (2007, p. 61), 'an unusual and interesting way of independent research work, high motivation, stimulating intellectual curiosity, respect for individual abilities, experience of group work, learning and application of different methods of work, development of collaborative relationships, (self)responsibility, and resolving unforeseen problem situations. 


\section{Frequency of the Application of Contemporary Work Strategies and Techniques of Critical Thinking}

The modern educational system places emphasis on understanding concepts, active, independent, and collaborative fact-finding, and content. Precisely in such a teaching process does teaching collaborative work strategies become inevitable. Below are the results of the differences between teachers who reported an irregular implementation and those who reported a regular implementation of projects in the application of various contemporary work strategies.

The t-test for independent samples (Table 4) showed that teachers who reported more regular project activities in their schools at the class level more often applied almost all contemporary work strategies than teachers who carried out project activities irregularly did: 'application of group activities' $(t=$ $-3.382, \mathrm{p}=.01$ ), 'organisation of individualised work' (taking into account different pupil abilities) $(\mathrm{t}=-2.878, \mathrm{p}=.01)$, 'application of problem teaching' (identifying problems, problem questions, solutions) $(t=-3.188, p=.01)$, 'exploratory learning through research' (observing, monitoring, collecting, researching, etc.) $(\mathrm{t}=-2.085, \mathrm{p}=.04)$, and 'integrated theme days in the form of project teaching' $(t=-4.083, p=.01)$. Considering curricular principles and the competence development of pupils, problem-teaching of exploratory learning strategies is oriented toward the development of skills, methods, and techniques of coping and active problem solving; it promotes and develops pupils' independence for intellectual activities.

A statistically significant difference between the two groups of teachers was not found in the application of 'exploratory learning through simulation' (role-plays, games with rules, case studies, etc.) $(t=-1.780, p=.08)$.

The $t$-test for independent samples (Table 4) showed that teachers who reported more regular project activities at the level of the entire school more often implemented the following contemporary work strategies than teachers who reported the irregular implementation of project activities in their schools did: 'application of group activities' $(t=-3.249, p=.01)$, 'organisation of individualised work' (taking into account different pupil abilities) $(\mathrm{t}=-2.312, \mathrm{p}=$ .02), 'application of problem teaching' (identifying problems, problem questions, solutions) $(\mathrm{t}=-2.456, \mathrm{p}=.02)$, and 'integrated theme days in the form of project teaching' $(t=-2.613, p=.01)$. Creitare (2009, p.119) emphasises 'the wealth of different theoretical and practical approaches and gains the ability to perform them by adapting to teamwork, collaboration and acceptance of other opinions. There was no statistically significant difference between the two groups of teachers in the application of 'exploratory learning through research' 
(observing, monitoring, collecting, researching...) $(\mathrm{t}=-.572, \mathrm{p}=.57)$ and 'exploratory learning through simulation' (role-plays, games with rules, case studies ...) $(\mathrm{t}=-890, \mathrm{p}=.37)$. Precisely Craft et al. (2007) pointed out that over the last decade an increasing number of teachers have been using their professional skills and attempting to teach creatively by applying methods of problem solving with creative thinking and fostering and encouraging children's creativity.

Table 4

Frequency of the application of work strategies (at the level of class teaching and the entire school)

\begin{tabular}{|c|c|c|c|c|c|c|c|c|c|c|c|c|}
\hline \multirow{2}{*}{ Work strategy } & & & \multicolumn{5}{|c|}{ The class level } & \multicolumn{5}{|c|}{ The school level } \\
\hline & & & $\bar{x}$ & s & $\mathrm{t}$ & df & $\mathrm{p}$ & $\bar{x}$ & s & $t$ & df & $p$ \\
\hline \multirow{2}{*}{$\begin{array}{l}\text { Application of } \\
\text { group activities }\end{array}$} & $\mathrm{N}$ & 73 & 3.55 & 1.041 & \multirow[t]{2}{*}{-3.382} & \multirow[t]{2}{*}{113.215} & \multirow[t]{2}{*}{$.01^{*}$} & 3.55 & 1.025 & \multirow{2}{*}{-3.249} & \multirow[t]{2}{*}{125.2} & \multirow[t]{2}{*}{$.01^{*}$} \\
\hline & $\mathrm{R}$ & 143 & 4.01 & .769 & & & & 3.99 & .803 & & & \\
\hline \multirow{3}{*}{$\begin{array}{l}\text { Organisation of } \\
\text { individualised } \\
\text { work }\end{array}$} & $\mathrm{N}$ & 73 & 3.77 & .858 & \multirow{3}{*}{-2.878} & \multirow{3}{*}{214} & \multirow{3}{*}{$.01^{*}$} & 3.82 & .828 & \multirow{3}{*}{-2.312} & \multirow{3}{*}{216} & \multirow{3}{*}{$.02^{*}$} \\
\hline & & & & & & & & & & & & \\
\hline & $\mathrm{R}$ & 143 & 4.1 & .794 & & & & 4.08 & .812 & & & \\
\hline \multirow{2}{*}{$\begin{array}{l}\text { Application of } \\
\text { problem teaching }\end{array}$} & $\mathrm{N}$ & 73 & 3.63 & .842 & \multirow{2}{*}{-3.188} & \multirow{2}{*}{121.286} & \multirow{2}{*}{$.01^{*}$} & 3.68 & .820 & \multirow{2}{*}{-2.456} & \multirow{2}{*}{135.3} & \multirow{2}{*}{$.02^{* *}$} \\
\hline & $\mathrm{R}$ & 142 & 3.99 & 679 & & & & 3.96 & .706 & & & \\
\hline \multirow{3}{*}{$\begin{array}{l}\text { Exploratory } \\
\text { learning through } \\
\text { research }\end{array}$} & $\mathrm{N}$ & 73 & 3.79 & .686 & \multirow{3}{*}{-2.085} & \multirow{3}{*}{213} & \multirow{3}{*}{$.04^{* *}$} & 3.88 & .692 & \multirow{3}{*}{-.572} & \multirow{3}{*}{215} & \multirow{3}{*}{.57} \\
\hline & & & & & & & & & & & & \\
\hline & $\mathrm{R}$ & 142 & 4.01 & .753 & & & & 3.94 & .791 & & & \\
\hline \multirow{3}{*}{$\begin{array}{l}\text { Exploratory } \\
\text { learning through } \\
\text { simulation }\end{array}$} & $\mathrm{N}$ & 73 & 3.85 & .72 & \multirow{3}{*}{-1.78} & \multirow{3}{*}{214} & & 3.89 & .741 & & & \\
\hline & & & & & & & .08 & & & -.89 & 216 & .37 \\
\hline & $\mathrm{R}$ & 143 & 4.04 & .768 & & & & 3.99 & .794 & & & \\
\hline Integrated theme & $\mathrm{N}$ & 73 & 3.6 & .878 & & & & 3.72 & .873 & & & \\
\hline $\begin{array}{l}\text { days in the form } \\
\text { of project teach- }\end{array}$ & & & & & -4.083 & 214 & $.01^{*}$ & & & -2.613 & 216 & $.01^{*}$ \\
\hline ing & $\mathrm{R}$ & 143 & 4.1 & .825 & & & & 4.04 & .849 & & & \\
\hline
\end{tabular}

Note. $\mathrm{N}=$ irregular project activities; $\mathrm{R}=$ regular project activities.

${ }^{*} p<.01 .{ }^{* *} p<.05$.

The results of the t-test for independent samples (Table 5) showed that teachers who reported the regular implementation of project activities at the class level more often applied techniques of critical thinking $(\mathrm{t}=-1.963, \mathrm{p}=$ .05) than teachers who reported irregular implementation of project activities did, while at the school level there were no statistically significant differences between the two groups of teachers. 
Table 5

T-test for independent samples: differences in frequency of application of techniques of critical thinking at the class level and at the school level as part of the implementation of project activities

\begin{tabular}{lllllllllll}
\hline $\begin{array}{l}\text { Application of the technique } \\
\text { of critical thinking }\end{array}$ & $\begin{array}{l}\text { Project } \\
\text { activities }\end{array}$ & $\mathbf{N}$ & $\overline{\boldsymbol{x}}$ & $\mathbf{s}$ & $\mathbf{F}$ & $\mathbf{p}$ & $\mathbf{t}$ & $\mathrm{df}$ & $\mathbf{p}$ \\
\hline & Irregular & 73 & 3.85 & .720 & & & & & \\
The class level & Regular & 143 & 4.07 & .811 & .763 & .38 & -1.963 & 214 & $.05^{*}$ \\
& Irregular & 76 & 3.87 & .772 & & & & & \\
\hline & Regular & 142 & 4.06 & .783 & & & & & \\
\hline
\end{tabular}

Note. ${ }^{*} p<.05$.

The results suggested that teachers who reported the regular implementation of project activities attach significance to the active role of pupils who use their skills, resources, and tools to 'ask questions, critically think and learn, make conclusions and decisions, apply knowledge to new situations and create new knowledge' (Schultz Jones, 2010, p.14).

ANOVA results (Table 6) showed that there were statistically significant differences between the counties in the application of techniques of critical thinking $(\mathrm{F}=3.736, \mathrm{p}=.025)$, i.e. it was determined that teachers from Istra County $(\bar{x}=4.04)$ applied techniques of critical thinking more often than teachers from Lika-Senj County $(\bar{x}=3.79)$ did.

Table 6

One-way ANOVA: differences between counties in the frequency of the application of techniques of critical thinking

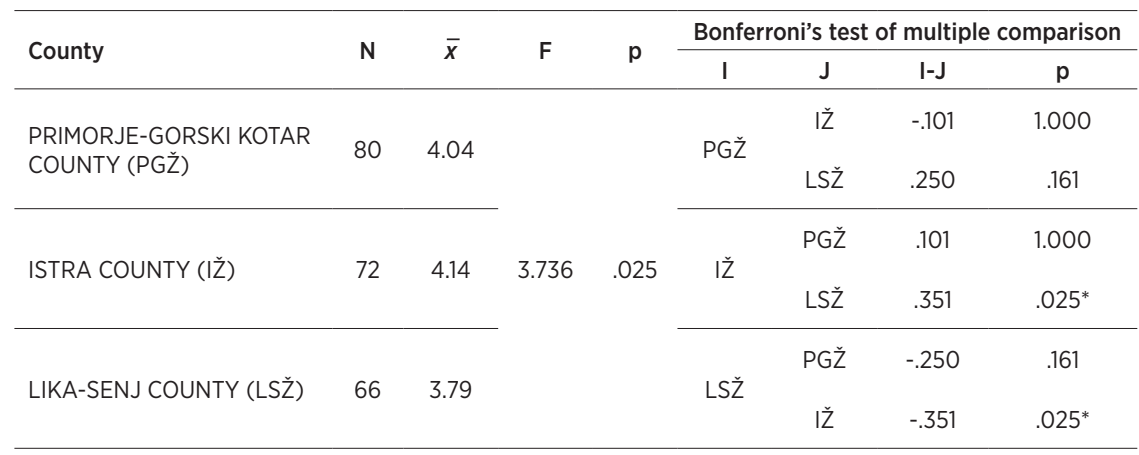


No statistically significant differences were found in the application of techniques of critical thinking with regards to other socio-demographic indicators.

\section{Teachers' Attitudes on the Contemporary Paradigm of Childhood and the Educational Process}

The role of the teacher is to encourage and guide the pupils in discovering and exploring new knowledge. As Jelavić (2008, p. 183) highlighted:

insight/ knowledge is expressed as the unity of the empirical and rational, the experiential and reflective. The pupil is given the opportunity to discover, create knowledge by collecting relevant data, facts, information, through generalizing, creating, and defining terms, rules, laws, conclusions, by applying knowledge in everyday life, noticing, and solving problems.

With this approach in the contemporary educational process, the teacher, instead of ready-made answers about the world that surrounds the pupil, enables the pupils to engage in an independent detection and investigation of that world.

The t-test for independent samples (Table 7) showed that teachers who reported more regular project activities in their schools at the class level demonstrated more compliance with the contemporary paradigm of childhood and the educational process than teachers who reported irregular implementation of project activities did, and they did so in the following items: 'Pupils should be allowed to discover their own truths and theories (even if inaccurate) through active and direct research, but they should not be taught facts' $(\mathrm{t}=-3.346, \mathrm{p}$ $=.01$ ), and 'The process in which a pupil seeks a solution is more important than the result itself' $(t=-2.365, p=.02)$. However, teachers who reported the regular implementation of project activities also showed an agreement with the traditional paradigm of childhood and the educational process in the following items: 'A pupil learns best in those activities that have been planned and designed by the teacher' ( $t=-2.721, p=.01$ ), 'For successful learning of more demanding content (e.g. scientific phenomena) it is necessary that the teacher lead and direct activities, while the pupil can learn less demanding content on his own' ( $\mathrm{t}=-1.973, \mathrm{p}=.05)$, and 'For the pupil to actually learn something it is important that the teacher teach the content, demonstrate, explain, reveal facts, and highlight important conclusions' $(\mathrm{t}=-2.608, \mathrm{p}=.01)$. There was no statistically significant difference between the two groups of teachers on the item "Pupils should be allowed to create, plan, and manage their activities instead of activities being precisely planned by the teacher" $(\mathrm{t}=-.418, \mathrm{p}=.68)$. 
Table 7

Teachers' attitudes on the contemporary paradigm of childhood and the educational process (at the class level and at the school level)

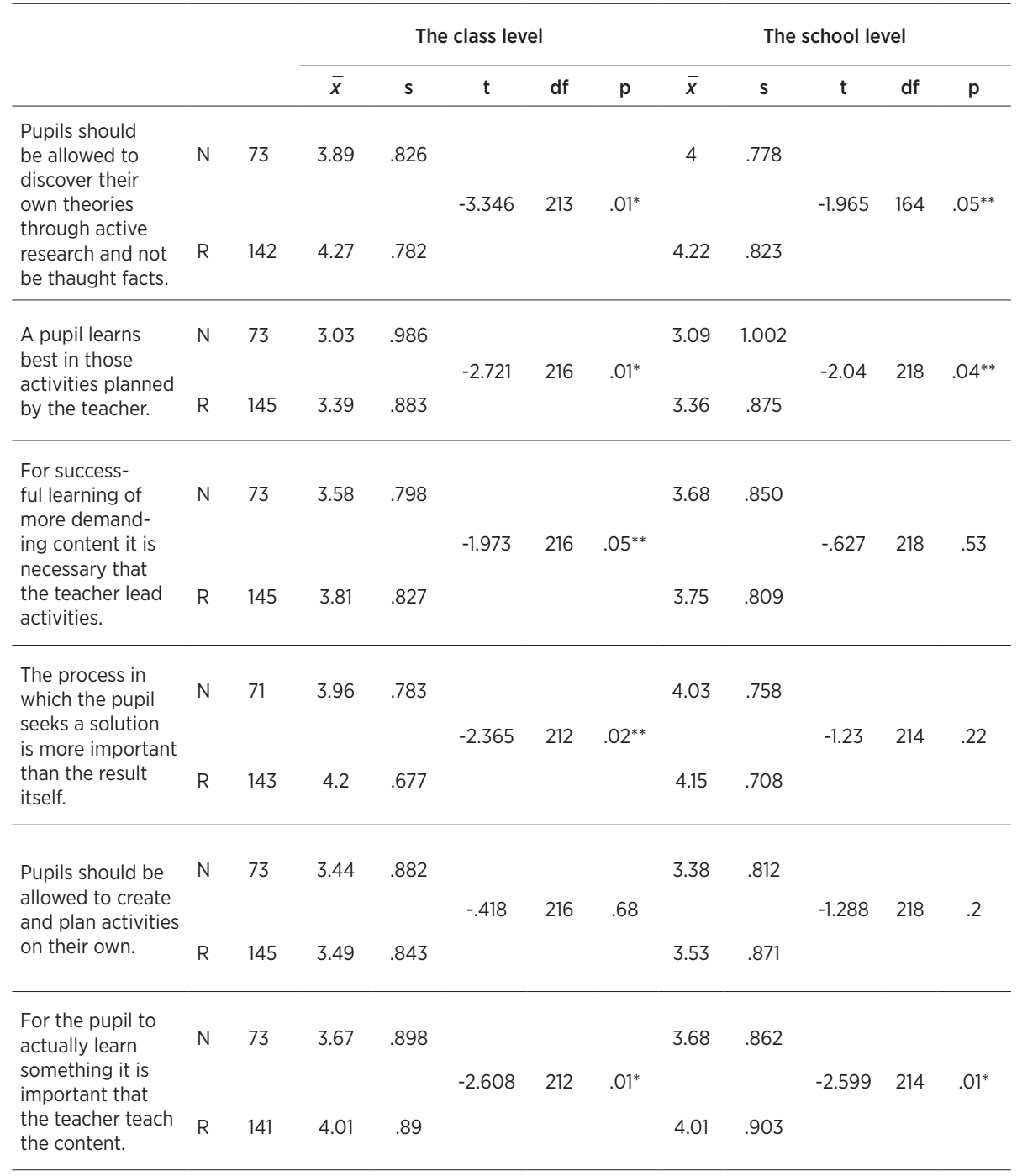

Note. $\mathrm{N}=$ irregular project activities; $\mathrm{R}=$ regular project activities.

${ }^{*} p<.01$. ${ }^{* *} p<.05$.

The t-test for independent samples (Table 7) showed that teachers who reported more regular project activities at the level of the entire school demonstrated more compliance with the contemporary paradigm of childhood and 
the educational process than teachers who reported irregular implementation of project activities in the item 'Pupils should be allowed to discover their own truths and theories (even if inaccurate) through active and direct research, but they should not be taught facts' $(t=-1.965, \mathrm{p}=.05)$. However, they also showed greater agreement with the traditional paradigm of childhood and the educational process than teachers who reported irregular implementation of project activities in the following items: 'A pupil learns best in those activities that have been planned and designed by the teacher' $(t=-2.040, p=.04)$ and 'For the pupil to actually learn something it is important that the teacher teach the content, demonstrate, explain, reveal facts, and highlight important conclusions' ( $t$ $=-2.599, \mathrm{p}=.01)$.

There was no statistically significant difference between the two groups of teachers in the following items: for successful learning of demanding content (e.g. scientific phenomena) it is necessary that the teacher guides and directs it, while the pupil can learn less demanding content on his own $(\mathrm{t}=-.627, \mathrm{p}=$ .53), 'The process in which a pupil seeks a solution is more important than the result itself' ( $\mathrm{t}=-1.230, \mathrm{p}=.22$ ), and 'Pupils should be allowed to create, plan, and manage their activities instead of activities being precisely planned by the teacher' $(t=-1.288, p=.20)$. Bernes (2007, p. 147) noted that 'without the pupils' engagement there can be no true learning. In line with this approach, there is a clear need to involve pupils in the design, planning, and management of research activities, understanding of the process of learning and developing their own criteria for success. As Railsbach (2002, according to Genc, 2015) points out, as a model of learning project learning encourages collaboration among pupils, develops pupil planning skills, decision-making and taking responsibility. Learners learn how to manage time effectively and solve an existing problem that makes it easier to connect learning content to the real world and contributes to the permanent retention of the information received.

\section{Conclusion}

The results indicated a frequent implementation of project activities at the level of both the class and the entire school. Teachers who reported the regular implementation of project activities in their schools more frequently consulted contemporary forms of group activities and individualised work, thereby taking into account different pupils' abilities. They noted applying problemteaching strategies of exploratory learning, research methods, planning thematically integrated teaching, and applying techniques of critical thinking. 
Enabling the pupils to develop critical thinking contributes to the formation of an independent, active, creative, and responsible person, who will find ways to reach goals based on their own opinion. This way the pupil will be able to connect new knowledge with previous knowledge, assess their values, and thereby build their own distinctive learning schemes, taking up an active role in teaching. Teachers are expected to encourage high-quality work with the possibility of finding solutions to different situations, to allow pupils to express their needs, to include as many senses as possible, to actively and independently demonstrate content, to use acquired knowledge, to correct their errors, and to develop their dispositions and tendencies.

However, the results showed that, unrelated to the teaching and teaching collaborative methods and work strategies, the present content correlation and integration, and adjustment of the teaching content to the pupils' interests, teachers estimated a frequent use of established approaches to the educational process (the teacher should explain, present the facts, and highlight important conclusions, while the pupil learns best during activities that have been planned and devised by the teacher). The impetus to develop critical thinking and research curiosity in pupils while working on project activities essentially reflects two key objectives: to learn how to explore everything that surrounds the pupil, and to take responsibility and initiative for independent work and collaborative activities, as well as to create space for the pupils' critical thinking. Critical thinking contributes to the development of learning and teaching. The results provide room for further reflection on the purpose of quality didacticmethodic advancements in planning and programming learning and teaching project activities.

\section{Acknowledgements}

This paper was funded by the University of Rijeka within research project 'Culture of Educational Institution as a Factor in Co-construction of Knowledge' (head of the project: Lidija Vujičić; grant number: 13.10.2.2.01). 


\section{References}

Barnes, J. (2007). Cross-curricular Learning 3-14. London: Paul Chapman Publishing.

Bezinović P., Marušić I., \& Ristić Dedić Z. (2012). Opažanja i unaprijeđivanje školske nastave

[Observations and Improvement of School Teaching]. Zagreb: Agencija za odgoj i obrazovanje.

Bognar, L., \& Matijević, M. (2002). Didaktika [Didactics]. Zagreb: Školska knjiga.

Bowel, T., \& Kemp, G. (2010). Critical thinking: A Concise Guide. London, New York: Routledge.

Cindrić, M. (2006). Projektna nastava i njezine primjene u nastavi fizike u osnovnoj školi [Project-

based Learning and its Application in Teaching Physics in Elementary School]. Magistra ladertina,

1(1), 33-47.

Cindrić, M., Miljković, Đ., \& Strugar, V. (2010). Didaktika i kurikulum [Didactics and the

Curriculum]. Zagreb: IEP-D2.

Craft, A., Cremin, T., Chappell, K., \& Burnard, P. (2007). Possibility thinking and creative learning.

In A. Craft, T. Cremin, \& P. Burnard (Eds.), Creative learning (pp. 3-11). Stoke-on-Trent: Trentham.

Creitaru, A. (2009). The Use of the Project Method in Teaching Mechanics as a Technical

Discipline. Seria Stiintele Educatiei, 61(2), 119-126.

Crnković-Nosić V. (2007). Projekt u nastavi hrvatskog jezika [Project Method in Teaching Croatian

Language]. Život i škola: časopis za teoriju i praksu odgoja i obrazovanja, LIII(18), 57-63.

Čudina-Obradović, M., \& Brajković, S. (2009). Integrirano poučavanje [Integrated Teaching]. Zagreb:

Pučko otvoreno učilište Korak po korak.

Danielson, C. (2013). Enhancing professional practice: a frameworkfor teaching2nd edition. Association for Supervision and Curriculum Development. Alexandria, VA.

Fabijanić, V. (2014). Projektna nastava: primjena u izradi istraživačkih radova učenika [Project-based learning: Application in the Writing of Students' Research Papers]. Educatio biologiae, 1(1), 89-96.

Ficher, A. (2001). Critical thinking. Cambridge: Cambridge University Press.

Genc, M. (2015). The project-based learning approach in environmental education. International

Research in Geographical and Environmental Education, 24(2), 105-117.

Harris, C. M., \& Zha, S. (2013). Concept mapping: A critical thinking technique. Education, 134(2),

207-211.

Jelavić, F. (2008). Didaktika [Didactics]. Zagreb: Naklada Slap.

Jensen, E. (2003). Super-nastava [Super-teaching]. Zagreb: Educa.

Knoll, M. (1997). The Project Method: Its Vocational Education Origin and International

Development. Journal of Industrial Teacher Education, 34(3), 59-80.

Knoll, M. (2014). Project Method. In D. C. Phillips (Ed.), Encyclopedia of Educational Theory and

Philosophy, Vol. 2 (pp. 665-669). London: Sage.

Matijević, M., \& Radovanović D. (2011). Nastava usmjerena na učenika [Student-oriented Teaching].

Zagreb: Školske novine.

Meyer, H. (2002). Didaktika razredne kvake [Didactics of the Classroom Catch]. Zagreb: Educa.

Peko, A. (2004). Projektna nastava [Project-based learning]. Život i škola: časopis za teoriju i praksu odgoja i obrazovanja, $L(11), 15-25$. 
Peko, A. (2006). Poticanje aktivnosti učenika projektnom nastavom. [Encouraging Students' Activity through Pedagogical Theory and Practice]. Napredak: časopis za pedagogijsku teoriju i praksu, 147(3), 492-502.

Peko, A., \& Varga, R. (2014). Active Learning in Classrooms. Život i škola: časopis za teoriju i praksu odgoja i obrazovanja, $L X(31), 59-73$.

Schultz Jones, B. (2010). School Librarians, Science Teachers + Optimal Learning Environments. Knowledge Quest, 39(2), 12-18.

Steele, J., Meredith, K., Temple, C., \& Walter, S. (2001). Čitanje i pisanje za kritičko mišljenje (Vodič kroz projekt I) [Critical Reading and Writing. (Guidelines through Project I)]. Zagreb: Forum za slobodu odgoja.

Terhart, E. (2001). Metode poučavanja i učenja [Teaching and Learning Methods]. Zagreb: Educa. Vuković, N. (2003). Mogućnost vrednovanja postignuća projektne nastave. [Possibility of Evaluating Achievements of Project-based learning]. Napredak: časopis za pedagogijsku teoriju i praksu, 144(2), $225-234$.

\section{Biographical note}

Petra Pejić Papak, PhD, is a pedagogue and an Assistant Professor at the Faculty of Teacher Education in Rijeka. She lectures several graduate courses as Didactics, Didactical Docimology, and Education and Teaching for Leisure Time at the Faculty of Teacher Education in Rijeka. She has published several scientific papers oriented to new approaches, strategies of teaching and learning, teacher competence, the importance of using modern technology in teaching, conducting research among teachers and students in primary school. She participated in many international and national scientific conferences and collaborated in several national and international projects. Currently, she participates in a research project "The Culture of Educational Institutions as a Factor in the (Co)construction of Knowledge“.

LidiJA Vujıčıć, $\mathrm{PhD}$, is a pedagogue and an Associate Professor at the Faculty of Teacher Education in Rijeka. Her scientific interests include: early and preschool education; new paradigm of the child and childhood, the culture of educational institutions; (co)construction of curriculum, initial education of preschool teachers; professional development of teachers/ preschool educators; action research. She teaches at the postgraduate doctoral study of pedagogy, held at the Faculty of Arts and Social Studies in Rijeka. She is currently leading the project entitled "The Culture of Educational Institutions as a Factor in the (Co) construction of Knowledge." 
ŽELJKA IvKović is an assistant at University of Rijeka, Faculty of Teacher Education, where she is engaged in sociological and methodological subjects. She is a doctoral candidate at University of Zagreb, Faculty of Humanities and Social Sciences, Department of Sociology. Her main research interests include economic socialization, sociology of childhood, and social status and feminisation of teacher profession in early, preschool and primary education. Currently, she participates in a research project "The Culture of Educational Institutions as a Factor in the (Co)construction of Knowledge" and Erasmus+ KA2 project „Modernisation, Education, Human Rights (MEHR)“. 